\title{
Death Domain
}

National Cancer Institute

\section{Source}

National Cancer Institute. Death Domain. NCI Thesaurus. Code C154635.

Reported mortality information for patients. 